Др Саша Ђ. Брадашевић Београдски универзитет

Филолошки факултет
$811.163 .41^{\prime} 367.4 ; 811.512 .161 ' 367.4$

doi 10.18485/analiff.2015.27.2.18

\title{
О ИСКАЗИВАЕЊУ ПРОСТОРНИХ ОДНОСА У СРПСКОМ И ТУРСКОМ ЈЕЗИКУ
}

\begin{abstract}
Нераскидива веза између просторно-временског континуума позната је не само у савременој лингвистици, већ и у најсавременијим открићима квантне физике. Овај рад разматра начин поимања просторних односа у језицима који припадају различитим језичким породицама. Када се упоређују типолошки различити језици као што су то турски и српски језик, појављују се разлике у начину исказивања просторних односа. То је најочигледније када се узме у обзир референтни објекат у односу на којег се врши одређивање положаја у простору.
\end{abstract}

Кључне речи: просторно-временски континуум, референтни систем, референтна тачка, референтни објекат, просторне релације, типологија језика, деикса.

Просторна и временска координација су способности које су својствене људским бићима и представљају кључ опстанка. Питањем сналажења у простору и времену се бавио познати филозоф Емануел Кант, према којем је наша просторна и временска интуиција аналитичка истина, према којој никакво емпиријско искуство није потребно да бисмо ствари организовали у простору и времену. [Кант, 1781, 121] Овакво учење је наставак филозофије александијског математичара Еуклида из 3.века п.н.е који нам је омогућио да положај сваке тачке у простору тачно одредимо уз помоћ три координате [Хофман 1975, 87]. Тај такозвани Еуклидов простор је ништа друго него наш референтни систем у којем позиционирамо било који објекат из нашег непосредног искуства. Наравно, ми ни не морамо да поседујемо било какво знање из геометрије да бисмо могли успешно да се сналазимо у простору и времену. Та урођена способност својствена људима је ништа дуго него просторна интуиција која нам помаже да организујемо чула и искуство у јединствени Еуклидов простор или референтни систем. 
У лингвистици је одавно позната чињеница да се из просторних односа, путем апстракције, изводе временски односи. У језику тако постоји нераскидива веза између између временске и просторне интуиције што је од кључне важности за употребу и разумевање језика.

Центар нашег референтног система је референтна тачка од које се све мери, а то је тачка на којој се налази посматрач. То је релативна и субјективна референтна тачка, зато што наше људске способности одређују ту „позицију” у времену и простору. Иако је избор те тачке субјективан или релативан, целокупно позиционирање мора бити унутар једног координатног система који је исти за све. Мерење унутар тог координатног система мора се обављати из једне референтне тачке. У физици на пример, референтна тачка представља почетак координатног система, тачку која је статична и од које се све мери. Слична ситуација је и у језику само са једном малом разликом. Иако ми постојимо у тродимензионалном или четверодимензионалном свету, интересантно је да у нашим изразима за позиционирање у времену или простору не користимо тродимензионални координатни систем. Насупрот томе, када се изражавамо о стварима или догађајима који се дешавају у свету који нас окружује ми радије користимо ортогонални или картезијански координатни систем да бисмо позиционирали ствари или догађаје. То је систем који је назван по француском филозофу Ренеу Декарту и односи се на дводимензионални простор или раван, на којем се било која тачка може представити само са две координате [ Декарт, 1960, 67]. Користећи се тим системом, ми преносимо нашу свакодневну конверзацију о положају одређеног предмета у простору тако што га описујемо са две координате координатног система. На пример, када кажемо да се неки предмет налази изнад, испред, лево или десно од неке референтне тачке ми несвесно изостављамо трећу координату. Наша просторна свест повезује две тачке у простору (тачка на којој се налази посматрач и тачка на којој се налази предмет посматрања) и успоставља везу између њих на основу информација које су релевантне за конверзацију, изостављајући ту трећу координату. Када неко показује на одређени објекат, релевантне информације укључују његов положај на хоризонталној или вертикалној равни, односно на једној од равни ортогоналног система (изнад-испод/ лево-десно/испред-иза).

У науци о језику се одувек полемисало о феномену референтног поља, у које смештамо наше језичко искуство, и референтне тачке која је центар тог референтног система. Тако се долази до појма деиксе о 
којој је говорио још старогрчки граматичар, Аполоније из Дискола који је живео у другом веку н.е, а велики допринос разумевању референтног система и референтне тачке је дао Карл Бухлер. По њему, деиктичко поље означава свет који нас окружује и оно је представљено координатним системом који је дефинисан скупом оса. Референтна тачка је центар тог система и означена је $(0,0,0)$ координатама и зове се ориго тачка [Бухлер, 1934: 128].

У случају просторних релација у језику ми не посматрамо ствари и догађаје у тродимензионалном свету или сферичном координатном систему.

Постоје случајеви када сам говорник није центар координатног система већ одређује свој положај у односу на нову ориго тачку. Разлог за такво померање налазимо у друштвеним релацијама и прагматици.

У данашње време универзализам као тренд има важно место у лингвистици. У науци о језику се појавило неколико теорија које оспоравају Сапир-Ворфову хипотезу лингвистичке релативности. На пример, Осгудов систием зајеgничкої значења, као и Гринбергов универзализам показују да постоји могућност успешног превода између језика који су наизглед веома удаљени.

Као што је већ било речи, ориго тачка или референтна тачка је најчешће сам говорник. У складу са положајем одређеног предмета у систему времена и простора говорник бира одређена језичка средства како би одредио позицију у односу на почетну или реферетну тачку. Када су у питању индоевропски језици, те речи помоћу којих се одређује положај у простору и времену су предлози. Међутим, то није случај у алтајској групи језика, поготово у турском језику. Турски језик нема предлоге па уместо њих користи именице. Ове именице могу да имају и временско и просторно значење тако што се трансформишу у йосийозиције, карактеристичне за турски језик. Када су у питању прецизни просторни односи а не апроксимације, тада се у турском језику не користе праве постпозиције већ кавазийосиийозиције које су као врста речи, именице [Ајкут, 2007: 10].

У турском језику је могуће просторне односе исказати и падежима без употребе икаквих постпозиција. Тада исказани просторни односи имају карактер апроксимације и нису прецизније одређени. Један од тих падежа је локатив. На пример:

Kitap masadadir.

Књига је на столу / Књига је у столу. 
У наведеном примеру, није прецизно одређен положај једног објекта у односу на други. Уместо тога је само речено да два објекта стоје у неком односу, с тим што је референтна тачка означена додавањем одговарајућег падежног наставка. Исто тако када се каже:

Kitap kimde? Код кога је књига?

Kitap Ayşe'dedir. Књига је код Ајше.

видимо да није важно где се одређени објекат тачно налази, већ да је важно да он стоји у одређеном односу са неким другим објектом.

Када је у питању аблатив (dan/den), може се рећи да је то падеж који у турском језику носи највише значења. Њему у српском језику одговарају предлози: из, og, $c a$ и збої [Ајкут, 2007: 105]. Аблатив маркира полазну или исходишну тачку од које се врши нека радња :

Dışarıdan geldi.

Дошао је извана.

Kuyudan su ald1.

Узела је воду из бунара.

Као и локатив, ни аблатив не одређује тачан положај неког објекта у односу на други, веч само чињеницу да он постоји. На тај начин, аблатив има функцију сличну локативу, када указује на место на којем се радња врши, маркирајући референтну тачку падежним наставком:

Ударио је змију у главу.

Yılanı başından vurdu.

Пољубио сам је у образ.

Yanağından öptüm.

Иако користе различита језичка средства ипак постоје сличности између референтних оквира у језицима који припадају различитим језичким породицама. Разлика је најприметнија у начину како се бира исходишна или референтна тачка, а она је условљена најпре друштвеним, а онда личним и емотивним захтевима.

У науци у језику су дефинисана три референтна система који су присутни у свим светским језицима. То су: унутрашњи, релативни и 
апсолутни референтни систем. Унутрашњи је бинаран по својој структури (однос између два објекта) и увек има почетну тачку везану за објекат, а не за субјекат. Тако на пример у српском и у турском језику имамо:

Неки човек је испред врата.

Bir adam kapının önündedir.

У наведеном примеру, особа је позиционирана у односу на предњу страну врата. Центар система, у овом случају је објекат који нити укључује полазну тачку говорника нити се одређује у односу на околину.

Унутрашњи референтни оквир је увек усмерен ка неком објекту и представља релацију између тог и још једног објекта. У труском језику постоје именице које представљају координатну осу као што су: горња страна, доња страна, предња страна итд. С обзиром да представљају нераздвојни део референтног објекта, ове се именице путем генитивне везе стављају у однос са неким објектом. На пример:

Kitap masanın üstündedir.

Књига је на столу.

Као што се види из примера, није коришћен само локатив јер би такво изражавање било напрецизно, већ се користи именица ӥst у значењу „, горња страна“, док српски користи предлог на. Именица која представља горњу страну, представља у ствари, равни део столице односно хоризонталну осу у координатном систему и њено значење је формирано на основу употребе, дакле, емпиријски. Друге именице које у турском језику представљају стране објекта су: $i c ̧$ (унутрашња страна), alt (доња страна), ön (предња страна), yan (бочна страна), arка (задња страна).

Поменуте површине такође бити подељене на три дела, све у складу са тачком гледишта посматрача или већ утврђеним кретањем неког објекта. Те постпозиције у турском су: baş (почетак, предњи део), dip (дно, доњи део) и orta (средина, средњи део) нпр.

Baba masanın başındadır.

Отац седи на челу стола. 
Dağın dibinde bir ev var.

Има једна кућа у подножју планине.

Са становиштва когнитивне лингвистике, може се рећи, када је у питању унутрашњи референтни оквир, да у трском језику прво долази референтни објекат па тек онда његов специфични део. Редослед речи је обрнут када је у питању српски језик.

Следећи референтни оквир је релативни оквир и састоји се од три члана. Њих представљају два објекта и говорник који је центар тог система. Може се рећи да је ово егоцентрични референтни систем. На пример:

Човек је лево од куће.

Adam evin sol tarafindadir.

У наведеном примеру референтни објекат је кућа, а други објекат (човек) је позициониран у односу на положај говорника. У турском језику су референтни објекат и исходишна тачка, повезани генитивном везом, будући да су обе именице као врста речи.

Приликом позиционирања једног објекта у односу на други, вежну улогу у турском језику игра и падежни систем. Када се на поменуту генитивну везу дода и одговарајући падеж могуће је прецизније одредити положај или путању неког објекта у односу на други. На пример:

Duvarın arkasında saklandi.

Сакрио се иза зида.

Duvarın arkasina saklandi.

Сакрио се иза зида.

У првом случају је употребљен локатив који са одговарајућом постпозицијом носи значење читавог простора или равни, без неког нарочитог прецизирања локације, будући да локатив није падеж кретања. У другом случају је употребљена конструкција са дативом, који је у турском падеж кретања ка неком циљу, указујући на то да се објекат налази непосредно иза неког другог објекта. У српском је оваква дистинкција редундандна. 
Што се тиче апсолутног референтног система, он исказује просторни однос између два објекта, али на такав начин да говорник није укључен, већ се тачан положај одређује у односу на географске координате. Овакав систем је апсолутно произвољан и претходно је дефинисан у складу са друштвеним околностима. Он није својствен индоевропским и алтајским језицима.

Српски и турски језик се разликују у начину како реализују исказе о просторним односима. Иако припадају различитим језичким породицама, у оба језика је заступљен и унутрашњи и релативни референтни оквир. Разлика је само у томе које место се бира за центар рефрентног система када је релативни референтни оквир у питању. Као и у модерној физици, тако и у превођењу постоји принцип неодређености. Када се настоји да се у потпуности прецизно преведе исказ који се односи на положај неког објекта, могућа су два исхода: ако је превод дослован, онда ће језик изгубити нешто од своје природе, и обрнуто.

\section{Литература}

Ајкут, К. (2007). Турске иоосиийозичие- "речи без значења". Задужбина Андрејевић, Београд.

Brain, L. (1963). Space, time and consciousness. Journal of Consciousness Studies, 10(3), 47-56.

Bühler, K. (1934). Sprachtheorie. Oxford, Fischer.

Casati, R., Smith, B., \& Varzi, A. (1998). Ontological tools for geographic representation. In:Formal ontology in information systems (pp. 77-85).

Descartes, R. ; Laurence J. Lafleur (trans.) (1960). Discourse on Method and Meditations. New York: The Liberal Arts Pres

Greenberg, J. (1963). Language and Linguistics. Behavioral Sciences Today. New York, Basic Books

Hawking, S. (2001). The Universe in a Nutshell, London, Bantam Press.

Hoffmann, K. (1975). Analysis in Euclidean Space. New Jersey, Prentice Hall. Jackendoff, R. (1990). Semantic structures. MIT Press, Cambridge, MA.

Jackendoff, R. (1996). The architecture of the linguistic-spatial interface. Language and space, 1-30.

Kalkar, J., (1996). Foundations of Quantum Physics, North Holland 
Kay, P., \& Kempton, W. (1984). What is the Sapir Whorf hypothesis? American Anthropologist, 86(1), 65-79.

Levinson, S.(1994). Frames of Reference and Molyneux's Question: Crosslinguistic Evidence, Language and Space Conference, Tucson, Arizona

Newton I., (1667), De Principia Mathematica [on line], available on: http:// www.wilbourhall.org/pdfs/newton/NewtonPrincipia.pdf [16.03.2010]

Schippan, T. (1983). K. Bühlers Organon-Modell der Sprache. STUF-Language Typology and Universals, 36(1-6), 543-552.

Talmy, L. (1983). How language structures space. In H. L. Pick, Jr., \& L. P. Acredolo (eds.), Spatial orientation: Theory, research, and application, NY, Plenum Press.

Teter, M. P., Payne, M. C., \& Allan, D. C. (1989). Solution of Schrödinger's Equation for Large Systems. Physical Review B,40(18), 12255.

Wassman, J. and P. Dasen. (1998). Balinese Spatial Orientation. Journal of Royal Anthropological Institute, 4(4)

Saša Bradašević

\section{Summary}

\section{ON EXPRESSING SPATIAL RELATIONS IN SERBIAN AND TURKISH}

In contemporary Serbian language, one can easily identify subordinate clauses by the type of conjunction that introduces them. The situation is quite different when it comes to the sentences in Turkish language, because at first sight one can say that there are no real conjunctions since Turkish belongs to the agglutinative languages group. Therefore, many word groups are subjects of conjunctivization process thus becoming the conjunctions. Besides that, many subordinate and coordinate clauses can be expressed simply by the syntactic order of subordinate and coordinate clauses.

Keywords: conjuctions, conjuctivizationa,subordinate clauses, coordinate clauses. 